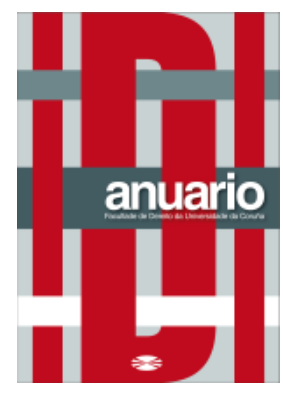

Anuario da Facultade de Dereito da Universidade da Coruña

Vol. 22 (2018), pp. 138-156

ISSNe: 2530-6324 || ISSN: 1138-039X

DOI: https://doi.org/10.17979/afdudc.2018.22.0.5206

\title{
INFRINGEMENT PROCEEDINGS AGAINST AZERBAIJAN: JUDICIALISATION OF THE EXECUTION OF THE JUDGMENTS OF THE EUROPEAN COURT OF HUMAN RIGHTS
}

\author{
ADRIENNE KOMANOVICS \\ Corvinus University of Budapest \\ Faculty of Social Sciences and International Relations
}

\begin{abstract}
During the last decades, States no longer tend to invoke the principle of noninterference when it comes to the scrutiny of their human rights record by peer review, reporting mechanisms or judicial procedures. Nevertheless, compliance with the recommendations or judgments of international human rights fora is a persistent concern in a number of States. Infringement proceedings was introduced in the Council of Europe only with Protocol 14 to the ECHR. While for quite a long time dormant, the procedure was invoked in December 2017 against Azerbaijan. This paper lays out the salient features of the procedure and explores whether non-execution could be effectively addressed by the judicialisation of the monitoring mechanism. Whereas the infringement procedure provides strong signals to other States with bad compliance record, it remains to be seen whether it will secure execution, due to the underlying political reasons of non-compliance.
\end{abstract}

Keywords: European Convention on Human Rights, European Court of Human Rights, Committe of Ministers, compliance with judgments, execution of judgments, infringement proceedings, monitoring mechanism 
Resumen: Durante las últimas décadas, los Estados no han en invocar el principio de no interferencia cuando han sido escrutados acerca de la aplicación de los derechos humanos por mecanismos de supervisión o procedimientos judiciales. No obstante, el cumplimiento con las recomendaciones o foros judiciales internacionales de derechos humanos es una preocupación en un buen número de estados. Los procedimientos de infracción fueron introducidos en el Consejo de Europa en el Protocolo 14 por el ECHR. Tras un tiempo de inaplicación, el procedimiento fue invocado en diciembre de 2017 contra Azerbaijan. Este artículo da cuenta de las principales cuestiones de dicho procedimiento.

Palabras clave: Convenio Europeo de Derechos Humanos, Tribunal Europeo de Derechos Humanos, Comité de Ministros, ejecución de las sentencias, procedimientos de infracción, mecanismo de supervisión

CONTENTS: I. INTRODUCTION. II. THE REASONS BEHIND NON-COMPLIANCE WITH THE CONVENTION. III. ARTICLE 46(4) OF THE ECHR: JUDICIALISATION OF NON-EXECUTION. IV. THE USE OF INFRINGEMENT PROCEEDINGS AGAINST AZERBAIJAN. V. CONCLUSIONS

To execute or not to execute: that is not the question. ${ }^{l}$

\section{INTRODUCTION}

During the last decades, States no longer tend to invoke the principle of non-interference when it comes to the scrutiny of their human rights record by peer review, reporting mechanisms or judicial procedures. ${ }^{2}$ Similar trends can be discerned in Europe as well, where the latest statistics on the execution of judgments of the European Convention on Human Rights $^{3}$ demonstrate the positive reception of the Convention system in the member States. ${ }^{4}$ Nevertheless, compliance with the recommendations or judgments of international human rights fora is a persistent concern in a number of States. According to the Committee of Ministers of the Council of Europe, sustained efforts are needed to improve the national implementation machinery, particularly with regard to violations revealing major complex or structural problems. ${ }^{5}$ Admittedly, quantification of compliance is not an easy exercise since besides monetary compensation, compliance with individual or general measures, if indicated at all by the Court, is much more complex.

1 Nils MUIŽNIEKS, the Commissioner for Human Rights of the Council of Europe, https://bit.ly/2E6pLfv

2 HIGGINS, R., "The United Nations at 70 years: The Impact upon International Law", ICLQ vol. 65, January 2016, pp. 1-19, at p. 9

3 Convention for the Protection of Human Rights and Fundamental Freedoms, ETS No.005, Rome, 4 November 1950

4 11th Annual Report of the Committee of Ministers 2017, p. 12

5 11th Annual Report of the Committee of Ministers 2017, p. 12 
Whereas certain aspects of compliance have been addressed by the author inter alia in this Anuario in 2016, ${ }^{6}$ this paper focuses on one particular method of ensuring compliance with judgments. Infringement proceedings, while a well-established procedure in the European Union, ${ }^{7}$ was introduced in the Council of Europe only with Protocol 14 to the European Convention on Human Rights, which was adopted in 2004, and entered into force in $2010{ }^{8}$ New paragraph 4 of Article 46 of the Convention, inserted by Protocol 14, stipulates that

If the Committee of Ministers considers that a High Contracting Party refuses to abide by a final judgment in a case to which it is a party, it may, after serving formal notice on that Party and by decision adopted by a majority vote of two thirds of the representatives entitled to sit on the Committee, refer to the Court the question whether that Party has failed to fulfil its obligation under paragraph 1.

Admittedly, the procedure should be brought only in exceptional circumstances, to provide an intermediate stage for the Committee of Ministers to convince the failing respondent State, before applying Article 8 of the Council of Europe's Statute, i.e. suspension of voting rights in the Committee of Ministers, or expulsion from the Organisation. ${ }^{9}$ It is not intended to provide for payment of a financial penalty. ${ }^{10}$

The objective of this paper is to lay out various issues surrounding the practical operation of the infringement proceedings. While for quite a long time dormant, the activation of the procedure in December 2017 against Azerbaijan gives a fresh impetus to the examination of this issue. Whereas triggering the so-called nuclear option is a welcome development in relation to recalcitrant States, and provides strong signals to other States with bad compliance record, it remains to be seen whether infringement proceedings will secure compliance, due to the underlying political reasons of non-compliance.

In what follows, Part Two provides a brief overview of the reasons behind non-compliance, which is followed by exploring whether non-execution could be effectively addressed by the judicialisation of the monitoring mechanism. Part Four examines the first application of Art. 46(4), against Azerbaijan, while Part Five concludes by discussing the limits of the infringement procedure in ensuring the effectiveness of the Convention system.

\section{THE REASONS BEHIND NON-COMPLIANCE WITH THE CONVENTION}

Compliance with international law is problematic since the international legal system lacks international police force and a mandatory judicial system. The limited means of enforcing international obligations are even more salient in international human rights law, which lacks the element of reciprocity typical in other fields of international law. ${ }^{11}$ Non-execution of

\footnotetext{
6 KOMANOVICS, A., "Transición del compromiso al cumplimiento: eficacia de los tribunales internacionales de derechos humanos", Anuario da Facultade de Dereito da Universidade da Coruña, № 20 , 2016, págs. 321-349; available at https://bit.ly/2OM5U9m

7 Art. 258 of the Treaty on the Functioning of the European Union.

8 Protocol No. 14 to the Convention for the Protection of Human Rights and Fundamental Freedoms, amending the control system of the Convention. Strasbourg, 13 May 2004, entry into force: 01 June 2010.

9 Explanatory Report to Protocol No. 14, para. 100, available at https://bit.ly/2zXDHnU

10 Explanatory Report to Protocol No. 14, para. 99.

11 HENRIKSEN, A., International Law, Oxford University Press, 2017 (pp. 15-17). On compliance with international law, see e.g. FRANCK, T.M., The Power of Legitimacy Among Nations, Oxford University Press, 1990; GUZMAN, A., How International Law Works: A Rational Choice Theory, Oxford University Press, 2008, pp. 33-71; COLE, W. (2015), Mind the Gap: State Capacity and the Implementation of Human Rights Treaties. International Organization 69 (2): 405-41; GOLDSMITH, J., and POSNER, E. (2005), The Limits of
} 
international human rights obligations is due to various factors, including the specific nature of international human rights law, the quality of the judges and the judgments, and the problems related to giving effect to the judgments.

International human rights treaties deal directly with the relations between public authorities and private actors within States. ${ }^{12}$ Compliance with treaty obligations is complicated by the fact that

... not only the human rights treaties as such need to be integrated in the domestic legal orders, but in addition the case-law of the respective judicial bodies imposes specific obligations concerning compliance with the judgments issued and with the interpretation given to the conventions by the international bodies. The case law of those bodies has an impact on the international obligations assumed by the States, and on the contents and scope of the rights and freedoms incorporated in the conventions. $^{13}$

In addition, human rights treaties establish special monitoring mechanisms, providing for multilateralized countermeasures. Such institutionalized machinery has, nevertheless, its limits. Thus, in the case of the European Convention on Human Rights, the Court exercises

... caution in interpreting the Convention. It does so by granting a margin of appreciation to States on those issues in which there is no broader consensus or which touch upon issues of culture or tradition that the member state government is best placed to evaluate. The optimal form of subsidiarity is when human rights issues are resolved at the national level in line with the case-law of the Court. ${ }^{14}$

Effectiveness of the Convention also depends on the quality of judges and the judgments. This issue has been explored in a previous article written by the author. ${ }^{15}$ Suffice it here to say that the Contracting Parties should set up appropriate national selection procedures to ensure that the strict criteria for the position be met. ${ }^{16}$ To maintain efficiency and authority of the Court, judges must hold the qualifications for office and be of "high moral character". ${ }^{17}$

International Law, New York: Oxford University Press; GOODMAN, R., and JINKS, D. (2008), "Incomplete Internalization and Compliance with Human Rights Law", European Journal of International Law 19 (4), pp. $725-48$.

12 On the relationship between international human rights treaties and municipal law, see e.g. BLACKBURN, R. and POLIAKIEWICZ, J., Fundamental rights in Europe: The European Convention on Human Rights and its member states, 1950-2000 (Oxford University Press, Oxford, 2001); VAN DIJK, P., VAN HOOF, F., VAN RIJN, A., and ZWAAK, L. (eds), Theory and Practice of the European Convention on Human Rights, 4th edition, Intersentia 2006; KELLER, H. and STONE SWEET, A. (eds.), A Europe of rights. The impact of the ECHR on National Legal Systems, Oxford University Press, 2006

13 European Commission for Democracy Through Law (Venice Commission), Report on the Implementation of International Human Rights Treaties in Domestic Law and the Role of Courts (Rome, 10-11 October 2014), CDL-AD(2014)036, para. 7.

14 Nils Muižniek, Council of Europe Commissioner for Human Rights, Written evidence (VEP 0053), UK Parliament Joint Committee on the draft Voting Eligibility (Prisoners) Bill, Oral and Written Evidence; 2013 , pp. 520-522, at p. 522; https://bit.ly/2NubgBj

15 KOMANOVICS, A., "Transición del compromiso al cumplimiento: eficacia de los tribunales internacionales de derechos humanos", Anuario da Facultade de Dereito da Universidade da Coruña, № 20 , 2016, págs. 321-349

16 On the selection of judges see e.g. MACKENZIE, R. and SANDS, P., "Judicial Selection for International Courts: Towards Common Principles and Practices," in Kate Malleson and Peter H. Russell (eds.), Appointing Judges in an Age of Judicial Power: Critical Perspectives From Around the World (University of Toronto Press, 2006); Ruth Mackenzie, Kate Malleson, Penny Martin, Philippe Sands, Selecting International Judges: Principle, Process, and Politics (Oxford University Press, 2010); Michael Bobek (ed.), Selecting Europe's Judges: A Critical Review of the Appointment Procedures to the European Courts (Oxford University Press, 2015); Report of the International Commission of Jurists and the Open Society Justice Initiative, Strengthening from Within. Law and Practice in the Selection of Human Rights Judges and Commissioners (2017 Open Society Foundations).

17 Art. 21 ECHR. The criteria require judges to be of high moral character, possess the qualifications required for appointment to high judicial office or be jurisconsults of recognised competence, sit in their individual capacity, and not to engage in any activity which is incompatible with their independence, impartiality or with 
A recent negative example could be the homophobic statements made by Judge Dedov in his separate opinion to the Bayev case, ${ }^{18}$ which related to a complaint brought by three gay rights activists about legislation in Russia banning the promotion of homosexuality. The majority of the Court held that the so-called "gay propaganda law" violated Article 10 (freedom of expression) and Article 14 (prohibition of discrimination) in conjunction with Article 10. Although the laws in question aimed primarily at protecting minors, the limits of those laws had not been clearly defined and their application had been arbitrary. In fact, by adopting such laws the authorities had reinforced stigma and prejudice and encouraged homophobia, which was incompatible with the values of a democratic society. ${ }^{19}$ In his separate opinion, Judge Dedov argued that

... the forcible informing of children without their desire or consent, in any form, about sex in general should be prevented; as regards non-traditional sex, it is a much more complex issue on which children should be informed as late as possible when they become mentally mature. ... The idea that same-sex sexual relations are normal indeed creates a situation where they are ready to engage in such relations, just because of the curiosity which is an integral part of a child's mind. [...] the purpose of the demonstration [was] to raise awareness of non-traditional sex, thus making children more vulnerable to sexual abuse.

Such a clear departure from the values of the Convention is unfortunately not restricted to this particular case ${ }^{20}$ or this particular judge. ${ }^{21}$ Obviously, the attitude of the members of the Court is influenced by numerous factors, such as the member's nationality, place of residence, current and past employment, membership of or affiliation with an organization, or family and social relations. However, by making such outrageously homophobic statements unworthy of a judge at the European Court of Human Rights, the Russian judge has certainly crossed a line. ${ }^{22}$

Besides the suitability of individuals to be elected as a judge, the quality, cogency and consistency of the judgments is also of paramount significance. ${ }^{23}$ Well-reasoned, clear judgments are generally easier to implement. To facilitate compliance, and supervision

the demands of a full-time office. See also See e.g. PACE Doc. 11767 of 1 December 2008, Nomination of candidates and election of judges to the European Court of Human Rights. Report of the Committee on Legal Affairs and Human Rights; Rapporteur: Christopher Chope, available at https://bit.ly/2QyB2X6

18 Bayev and Others v. Russia (Appl. nos. 67667/09, 44092/12 and 56717/12, judgment of 20 June 2017)

19 Bayev, para. 83. See the case note on Bayev by KOMANOVICS, A., "Az Emberi Jogok Európai Bíróságának ítélete az orosz melegpropaganda tilalmáról" [Judgment of the European Court of Human Rights on the ban of Russia on the promotion of homosexuality], Jogesetek Magyarázata 2018/1, Vol. IX Issue 1, pp. 6976, available at https://bit.ly/2OF0Rrp

${ }^{20}$ See the separate opinion of Judge Dedov in Trabajo Rueda v. Spain (Appl. no. 32600/12, judgment of 30 May 2017) and Z.A. and Others v. Russia (Appl. nos. 61411/15 and three others, Judgment of 28 March 2017).

21 See e.g. the separate opinion of Judge Loucaides in E.B. v France (Appl. No. 43546/02, Judgment of 22 January 2008): "Homosexuals ... must, like any other persons with some peculiarity, accept that they may not qualify for certain activities which, by their nature and under certain circumstances, are incompatible with their lifestyle or peculiarity." See also the separate opinion of Judge Pejchal and Judge Wojtyczek in Orlandi and Others v Italy (Appl. nos. 26431/12; 26742/12; 44057/12 and 60088/12, Judgment 14 December 2017), arguing that " $[\mathrm{m}]$ arriage in its initial meaning presupposes the community of lives between a man and a woman. ... The complementariness of the biological sexes of the two spouses is a constitutive element of marriage. Moreover, marriage in this meaning is - by definition - a social institution open to procreation."

22 LAVRYSEN, L., "Bayev and Others v. Russia: on Judge Dedov's outrageously homophobic dissent", 13 July 2017, available at https://bit.ly/2uA4KEt. See also ARMAS-CARDONA, G., "The Dissent in Bayev and Others v. Russia: A Window into an Illiberal World View", 7 July 2017; https://bit.ly/2Rzv21O; JOHNSON, P., "Homophobia in the European Court of Human Rights", 13 July 2017, https://bit.ly/2Plou5m; FALCETTA, S., "Critical consideration of the "disturbing" views of ECHR Judges Pejchal and Wojtyczek on same-sex relationships", 16 December 2017, https://bit.ly/2RwUODP

23 Steering Committee for Human Rights, Report on the longer-term future of the system of the European Convention on Human Rights, Strasbourg, 11 December 2015, CDDH(2015)R84 Addendum I, para. 96. 
thereof, in its judgments the Court should identify what it considers to be the underlying problem, and indicate more clearly which elements are actually problematic and can be regarded as the direct source of the violation. ${ }^{24}$

Finally, much depends on the attitude of States to comply. The United Nations Convention on the Law of Treaties, reflecting customary international law, provides in Art. 26 that once consent to be bound has been expressed and the treaty has entered into force, the treaty shall be kept by the parties in good faith. Art. 46(1) of the Convention stipulates that States shall abide by the final judgment of the Court in any case to which they are parties. In practice, however, States frequently relativize their international obligations when important interests and values are at stake, even at the price of incurring international responsibility.

In its 10th annual report on the Supervision of the Execution of Judgments and Decisions of the European Court of Human Rights of 2016, the Council of Ministers explicitly refers to four major types of difficulty facing the execution of Court judgments. These are the following:

- Important and complex structural problems and the resource implications of the reforms;

- The absence of a common understanding as to the scope of the execution measures required;

- Slow or blocked execution as a result of disagreement between national institutions, or amongst political parties, as regards the substance of the reforms required;

- A refusal to adopt the individual measures required or to pay just satisfaction, situations which frequently hide more fundamental disagreements with the Court's conclusions or the requirements of execution. ${ }^{25}$

Londras and Dzehtsiarou argue that non-compliance is due to mainly two factors: the political sensitivity of the case and the dilatoriness of the States. ${ }^{26}$ These two broadly conceived categories roughly corresponds with the four categories employed by the Council of Ministers: the "important and complex structural problems" as well as "the absence of a common understanding as to the scope of the execution measures required" might be subsumed under the dilatoriness category, whereas "slow or blocked execution" and "refusal to adopt measures" indicated in the judgment are linked to the political sensitivity of the issue.

As far as principled non-execution is concerned, Russia provides a clear example of a deeply rooted conviction that international decisions should not prevail over positions arrived at national level through democratic process. ${ }^{27}$ Indeed, in its judgment of 14 July 2015, the Constitutional Court of the Russian Federation made clear that "the Russian Constitution had priority, with the consequence that a decision from the ECtHR that contradicted the Russian Constitution could not be executed in Russia." ${ }^{28}$ The Russian Constitutional Court held that

$24 \mathrm{CDDH}(2015) \mathrm{R} 84$ Addendum I, para. 144.

25 Supervision of the Execution of Judgments and Decisions of the European Court of Human Rights, 10th Annual Report of the Committee of Ministers - 2016, Council of Europe, March 2017, p. 13.

26 DE LONDRAS, F. and DZEHTSIAROU, K., "Mission Impossible? Addressing Non-execution through Infringement Proceedings in the European Court of Human Rights", International and Comparative Law Quarterly, vol 66, April 2017, pp. 467-490

27 DE LONDRAS and DZEHTSIAROU (2017), p. 474. On the behavioural patterns of Russia see BÉKÉSI, L., The 12-Year Cycles - Society and Economy, AULA (1994/1.) pp.105-108.

${ }_{28}$ Venice Commission: Interim Opinion on the amendments to the Federal Constitutional Law on the Constitutional Court of the Russian Federation, Opinion no. 832/2015, CDL-AD(2016)005 (Interim Opinion), 
the Russian Federation is ... obliged to ensure the supremacy of the Constitution of the Russian Federation within the framework of its legal system, which forces it in the event of emerging of any collisions in this field ... to give preference to the requirements of the Constitution of the Russian Federation and thereby not follow literally the judgment of the European Court of Human Rights in the event if its execution contradicts constitutional values. ${ }^{29}$

Apart from this justification, based on a hierarchical argument, Russia also challenged the authority of the European Court of Human Rights to interpret the Convention in a broad manner. ${ }^{30}$

In 2016, this decision was followed by an amendment to the 1994 Federal Constitutional Law on the Constitutional Court of the Russian Federation, which vested the President and the Government with the power to petition the Constitutional Court to monitor the compatibility of the decision of interstate human rights protection institutions with the Russian Constitution. Should the Constitutional find a contradiction, the international decision cannot be enforced by the Russian authorities. ${ }^{31}$ In fact, the Russian Constitutional Court has already denied enforcement of the Strasbourg Court's decision in Anchugov and Gladkov, concerning Russia's blanket ban on convicted prisoners' voting rights, ${ }^{32}$ and in Yukos, relating to the tax and enforcement proceedings brought against Yukos, which led to its liquidation. ${ }^{33}$

Currently the priority areas requiring attention relate to inadequate control of police actions, different issues related to the lawfulness of detention, poor detention conditions, inefficient judiciaries, ensuring compensation or restitution for properties nationalised under former communist regimes, excessive restrictions of freedom of assembly and association, the legal framework surrounding actions of security forces and the effectiveness of investigations into

para. 14. https://bit.ly/1Mkvw1G. See also Venice Commission: Russian Federation. Final Opinion on the amendments to the Federal Constitutional Law on the Constitutional Court, Opinion no. 832/2015, CDLAD(2016)016, https://bit.ly/1UhhnIn

${ }^{29}$ Cited in Venice Commission, Interim Opinion (2016), para. 16.

30 D'AMBROSIO, D.R., "The Supremacy of the Russian Constitutional Court? Summary of Venice Commission Opinion no. 832/2015”, EHRAC Bulletin | Winter 2016, pp. 10-11, p. 11.

31 See Amendments to the Federal Constitutional Law on the Constitutional Court of the Russian Federation of 14 December 2015, reproduced in European Commission for Democracy Through Law (Venice Commission), CDL-REF(2016)006, Strasbourg, 20 January 2016 (Translation provided by the Constitutional Court of the Russian Federation), English version available at https://bit.ly/2y8tRyb

32 Anchugov and Gladkov v. Russia (Appl. nos. 11157/04 and 15162/05), Judgment of 4 July 2013. On 2 February 2016, the Ministry of Justice of the Russian Federation appealed to the Russian Constitutional Court regarding the possible inability to enforce the judgment of the ECtHR in the case of "Anchugov and Gladkov v. Russia" of 3 July 2013. The Russian Court found that executing the judgment of the ECtHR may contradict the Constitution, thus the ECtHR's decision cannot be enforced / executed. See the judgment in English at https://bit.ly/2PkUW81. See also ABASHIDZE, A.Kh., ILYASHEVICH, M.V. and SOLNTSEV, A.M., Anchugov \& Gladkov v. Russia, AJIL, Volume 111, April 2017, pp. 461-468; CHAEVA, N., "The Russian Constitutional Court and its Actual Control over the ECtHR Judgment in Anchugov and Gladkov", 26 April 2016, https://bit.ly/2OIb4TN; AKSENOVA, M, "Anchugov and Gladkov is not Enforceable: the Russian Constitutional Court Opines in its First ECtHR Implementation Case", 25 April 2016, https://bit.ly/2QxzFbh

33 OAO Neftyanaya Kompaniya Yukos v. Russia (Appl. no. 14902/04), Judgment of 20 September 2011. The question of just satisfaction was not ready for decision at the time of the judgment on the merits, and had to be decided in a separate judgment of 31 July 2014 (Just satisfaction). See e.g. PHILIPPOV, I., "Russian Constitutional court denies enforcement of ECHR decision on Yukos", 25 January 2017, https://bit.ly/2ICMT6m, or https://bit.ly/2tvTKbs. See also Supervision of the Execution of Judgments and Decisions of the European Court of Human Rights, 10th Annual Report of the Committee of Ministers - 2016, Council of Europe, March 2017, p. 248. 
alleged illegal or excessive use of force. ${ }^{34}$ While some of these issues emanate from principle, others are due to the financial implications of the case.

Londras and Dzehtsiarou argue that dilatoriness on the part of States stem from problems of "corruption, autocracy, geopolitics, formal legality without commitment to the liberal construction of the Rule of Law, and systematic disregard for judicial authority and, in some cases, independence". ${ }^{35}$ This can readily be seen in the case of Azerbaijan, which became the first State to be served a referral decision under Art. 46(4). Human rights are under serious challenge there, as evidenced by various reports. According to Amnesty International, in Azerbaijan

Authorities intensified the crackdown on the right to freedom of expression, particularly following revelations of large-scale political corruption. Independent news outlets were blocked and their owners arrested. Critics of the government continued to face politically motivated prosecution and imprisonment following unfair trials. LGBTI individuals were arbitrarily arrested and ill-treated. Suspicious deaths in custody were still not effectively investigated. ${ }^{36}$

Before examining the background of the Committee of Ministers' decision to launch infringement proceedings against Azerbaijan, the paper lays out the general scheme of Art. 46(4) of the Convention.

\section{ARTICLE 46(4) OF THE ECHR: JUDICIALISATION OF NON-EXECUTION}

In order to enhance the effectiveness of the Convention control system, various measures have been introduced by Protocol 14, including the clarificatory interpretation of judgments in Art. 46(3), ${ }^{37}$ as well as the infringement proceedings in Art. 46 paras. (4) and (5).

The decision to refer the case to the Court, which should be made only in exceptional circumstances, shall be adopted by a two-thirds majority of the Committee of Ministers. The State concerned will be formally notified and will be given another six months to implement the judgment. The referral decision shall be reasoned, and shall reflect the views of the respondent State as well. ${ }^{38}$ The proceedings are conducted before the Grand Chamber. ${ }^{39}$ This procedure does not foresee the imposition of financial penalty, because it was felt that the political pressure exerted by the infringement proceeding should secure compliance with Court's initial judgment. ${ }^{40}$

Until December 2017, the Committee of Ministers has refrained from invoking this procedure, even though in 2012 "a first major push has been made to induce the Committee of

\footnotetext{
34 Supervision of the Execution of Judgments and Decisions of the European Court of Human Rights; 11th Annual Report of the Committee of Ministers 2017, pp. 7 and 12.

35 DE LONDRAS and DZEHTSIAROU (2017), p. 479

36 Azerbaijan 2017/2018, https://bit.ly/109vrUU. See also the report of Human Rights Watch at https://bit.ly/2Qz7qsM, and the Human Rights Report of the United States Department of State on Azerbaijan at https://bit.ly/2QCPwFH

37 The Committee of Ministers was vested with the power to ask the Court for an interpretation of a judgment, to assist the Committee of Ministers in determining what measures may be necessary to comply with a judgment.

38 Rule 11 (Infringement Proceedings) of the Rules of the Committee of Ministers for the supervision of the execution of judgments and of the terms of friendly settlements (2006).

39 ECHR Art. 31(b)

$40 \quad$ Explanatory Report, para. 99.
} 
Ministers to start infringement procedures" ${ }^{\circ 1}$ in Isayeva ${ }^{42}$ relating to an aerial attack by the Russian military on a village in Chechnya in February 2000. The first referral decision was adopted in the Mammadov case.

It is clear that the infringement procedure was introduced to provide the Council of Ministers with a wider range of means of pressure to secure execution of judgments. Various points must be noted in order to explore whether this judicialisation could actually safeguard and/or enhance the effectiveness of execution. ${ }^{43}$

The first note to be made relates to the locus standi: neither the Parliamentary Assembly nor the applicants were endowed with the right to trigger the procedure. The idea was "to give a political (and not a victim) approach to such an appeal. It was admitted that only the CoM (composed of ambassadors representative of the States) would be wise enough not to abuse such a power." ${ }^{4}$

Second, while supervision of execution is admittedly a partly political exercise, ${ }^{45}$ Art. 46(4) does not specify what is required in order to activate the infringement proceedings: how much time should have passed, if it is sufficient that the respondent State has failed to comply with the judgment or there must be an explicit refusal to do so. ${ }^{46}$ The Explanatory Report to Protocol 14 stipulates that it is essential to strengthen the means given to the Committee of Ministers in its supervisory powers "whenever the Committee of Ministers considers that one of the High Contracting Parties refuses, expressly or through its conduct, to comply with the Court's final judgment in a case". ${ }^{47}$ Thus, probably the correct conclusion is that implied defiance might be sufficient.

Then, achieving two-thirds majority in the Committee of Ministers seems a remote possibility or, in retrospect, slightly probable, all the more so since there are quite a few States with a high number of non-implemented judgments, facing serious structural problems. These States are generally reluctant to vote for the launch of an infringement proceedings against their peer. $^{48}$

Fourth, triggering the procedure implies a defeat on the part of the Committee of Ministers. Lambert-Abdelgawad argues that "... bringing a case to the Court on the ground of article 46(3) or (4) ECHR means that the CoM has failed in its function of supervising the implementation of the judgments; it will therefore probably be reluctant to display such a failure." ${ }^{49}$

41 BUYSE, A., 14 August 2012, https://bit.ly/2NvxItR

42 Isayeva v. Russian Federation (Appl. no. 57950/00; judgment of 24 February 2005)

43 The following section is largely based on the article of DE LONDRAS and DZEHTSIAROU (2017).

44 LAMBERT-ABDELGAWAD, E, 'The Court as a part of the Council of Europe: the Parliamentary Assembly and the Committee of Ministers' in Føllesdal, A, Peters, B and Ulfstein, G (eds), Constituting Europe: The European Court of Human Rights in a National, European and Global Context, Cambridge University Press 2013, 263-300, at p. 280

${ }_{45}$ States "do not leave their political motivations behind when they gather in Strasbourg", ÇALI, B. and KOCH, A., "Foxes Guarding the Foxes? The Peer Review of Human Rights Judgments by the Committee of Ministers of the Council of Europe", Human Rights Law Review, 2014, pp. 301-325, at p. 324

46 Nuala Mole's contribution to the event "Implementation of Judgments of the European Court of Human Rights: Opportunities and Challenges for the Rule of Law" organized by Bingham Centre for the Rule of Law and Leicester Law School, 15 May 2017, https://bit.ly/2hfMTh1

47 Explanatory Report to Protocol 14, para. 98.

48 DE LONDRAS and DZEHTSIAROU (2017), pp. 482-483

49 LAMBERT-ABDELGAWAD (2013) p. 280. 
Fifth, invoking Art. 46(4) may be counterproductive in the sense that the respondent State is unlikely to do anything to comply with the initial judgment during the infringement proceedings. ${ }^{50}$

Sixth, while clearly an exceptional measure, this procedure nevertheless increases the workload of the Grand Chamber, whose competence also includes relinquishment of jurisdiction by the Chambers; referrals against the decision of the Chambers; it also has to hold meetings to examine requests by the parties for cases to be referred to the Grand Chamber under Article 43 of the Convention; and it considers requests for advisory opinions.$^{51}$ While it is impossible to indicate the length of the infringement proceedings before the Court, judicial procedures are always time-consuming. In its 2017 Annual Report, the Committee of Ministers indicated that a judgment in the infringement proceedings against Azerbaijan is expected in the course of 2018, thus probably within one year from the referral decision. $^{52}$

Another point to note is the impact of this second judgment on the delinquent State. Will it provide a real incentive for abiding with the initial judgment? Why should the respondent State, which has failed to comply despite the initial judgment and the repeated calls by the Committee of Ministers, abide with a new judgment restating that the problem giving rise to the original judgment still exists $?^{53}$ The respondent State probably does not display an enhanced propensity, irrespective of whether its original reluctance stemmed from political considerations or the budgetary implications of the remedy. In fact, infringement proceedings might even prove to be counterproductive as it might fuel anti-Strasbourg sentiments, and fear about the loss of sovereignty and supremacy.

Finally, it must be recalled that there are no specific "sanctions" envisaged by Art. 46(4) of the Convention. Without providing for fines or penalties, any potential advantage of the procedure might prove to be illusory. ${ }^{54}$ If the Court finds that the respondent State has failed to comply with the initial judgment, it cannot do more than refer the case back to the Committee of Ministers for consideration of the measures to be taken.

Against this background, it is of great interest to follow the fate of the infringement procedure used for first time over a judgment against Azerbaijan on the opposition politician Mammadov.

\section{THE USE OF INFRINGEMENT PROCEEDINGS AGAINST AZERBAIJAN}

\footnotetext{
50 DE LONDRAS and DZEHTSIAROU (2017), p. 484.

51 Art. 31 ECHR. - In 2015, the Grand Chamber delivered 22 judgments in total (Annual Report of the European Court of Human Rights 2015, p. 65, available at https://bit.ly/2E5XA0a), in 2016, it delivered 27 judgments (Annual Report of the European Court of Human Rights 2016, p. 181, available at https://bit.ly/2zYCUDk), in 2017, it delivered 19 judgments and one inadmissibility decision (Annual Report of the European Court of Human Rights 2017, p. 155, available at https://bit.ly/2C2r0tk ).

52 11th Annual Report of the Committee of Ministers 2017, Supervision of the Execution of Judgments and Decisions of the European Court of Human Rights (Council of Europe, March 2018), p. 13). https://bit.ly/2BZTMed

53 DE LONDRAS and DZEHTSIAROU (2017), p. 486.

54 LAMBERT-ABDELGAWAD (2013) p. 280.
} 
This paper does not intend to provide a detailed description of the facts of the case. Suffice it here to say that the case concerned the detention of Ilgar Mammadov, a political opponent to punish him for his criticism of the government. In its judgment ${ }^{55}$ the Court found that that there had been a violation of Article 5(1) (right to liberty and security), Article 5(4) (right to judicial review of one's detention), Article 6(2) (presumption of innocence), and Article 18 (limitation on use of restrictions on rights) of the European Convention on Human Rights. ${ }^{56}$

The judgment in the Mammadov case was adopted on 22 May 2014, and in the following three years the Committee of Ministers has repeatedly called on Azerbaijan that the applicant be released immediately and urged the authorities to guarantee his physical integrity in the meantime. It stressed that the applicant remained imprisoned on the basis of the flawed proceedings. ${ }^{57}$

Admittedly, the Court's judgments are "essentially declaratory", ${ }^{58}$ thus States retain main responsibility for finding the most appropriate measures to ensure compliance with the Convention, having regard to the national circumstances. ${ }^{59}$ Nevertheless, the fact that the Supreme Court of Azerbaijan in 2016 decided to uphold the seven year-long prison sentence of Mammadov was in clear defiance of the Court's finding that Mammadov's deprivation of liberty was a punishment for having criticised the government. In its Interim Resolution of 2017, the Committee of Ministers noted that

the criminal proceedings against the applicant [was] concluded on 18 November 2016 before the Supreme Court without the consequences of the violations found by the European Court having been drawn; ${ }^{60}$

and that

the respondent State [is obliged], under Article $46 \S 1$ of the Convention, to abide by all final judgments in cases to which it has been a party and that this obligation entails, in addition to the payment of the just satisfaction awarded by the Court, the adoption by the authorities of the respondent State, where required, of individual measures to put an end to violations established and erase their consequences so as to achieve as far as possible restitutio in integrum ... ${ }^{61}$

55 Ilgar Mammadov v. Azerbaijan (Appl. no. 15172/13, Judgment of 22 May 2014)

56 The Court considered that Mr Mammadov, who had a history of criticising the Government, had been arrested and detained without any evidence to reasonably suspect him of having committed the offence with which he was charged, namely that of having organised actions leading to public disorder. The Court concluded that the actual purpose of his detention had been to silence or punish Mr Mammadov for criticising the Government and publishing information it was trying to hide. Press Release of the European Court of Human Rights, ECHR 144 (2014), 22.05.2014

57 Interim Resolution CM/ResDH(2015)43 (12 March 2015) - https://bit.ly/2E218jU, Interim Resolution CM/ResDH(2015)156 (24 September 2015) - https://bit.ly/2OHg2QQ; Interim Resolution CM/ResDH(2016)144 (8 June 2016) - https://bit.ly/2PmGRqG; Interim Resolution CM/ResDH(2017)379 (25 October 2017) https://bit.ly/2RAphRf; Interim Resolution CM/ResDH(2017)429 (5 December 2017) - https://bit.ly/2QzT3UW

58 See e.g. para. 58 of Marckx: "Admittedly, it is inevitable that the Court's decision will have effects extending beyond the confines of this particular case, especially since the violations found stem directly from the contested provisions and not from individual measures of implementation, but the decision cannot of itself annul or repeal these provisions: the Court's judgment is essentially declaratory and leaves to the State the choice of the means to be utilised in its domestic legal system for performance of its obligation under Article 53." Marckx v. Belgium, Appl. no. 6833/74, judgment of 13 June 1979. The application related to certain rules of Belgian law relating to inheritance rights of children born out of wedlock.

59 See e.g. CDDH(2015)R84 Addendum I, para. 17.

60 I.e., in view of the fundamental flaws in the criminal proceedings, the immediate and unconditional release of the applicant.

61 Interim Resolution CM/ResDH(2017)429, paras. e. and b. 
In consideration of Azerbaijan's failure to abide by the Court's judgment as well as the Committee's numerous subsequent decisions and interim resolutions stressing the fundamental flaws in the criminal proceedings, the Committee of Ministers decided to serve formal notice on the Republic of Azerbaijan of its intention to initiate the infringement proceedings, and invited Azerbaijan to submit its view on this question by 29 November $2017 .{ }^{62}$

In its views, Azerbaijan argued that as far as individual measures were concerned, it did pay the just satisfaction the Court had ordered, and with this it "remedied the deficiencies found in the proceedings leading to the applicant's conviction'. ${ }^{63}$ It listed a few general measures, including a visit by a mission set up by the Secretary General of the Council of Europe, a few changes to national laws, certain recommendations formulated by the President of Azerbaijan addressed to the Supreme Court, the General Prosecutor's Office and the Ministry of Justice in relation to the Code of Criminal Procedure and the Penal Code. Most importantly, however, Azerbaijan stressed that “... having regard to absence of the Court's any ruling to secure the applicant's immediate release and the discretion of the High Contracting Party to choose the means necessary to comply with the Court's judgment, the Government consider that they implement necessary measures to comply with the Court's judgment in the present case." ${ }^{\prime 64}$

Without going into the merits of the arguments, it must be noted first that, apart from just satisfaction, the Court rarely specifies the individual and general measures, thus respecting the principle of subsidiarity; and, second, that in its subsequent decisions and interim resolutions, the Committee of Ministers explicitly "expressed its very serious concern about the fact that the applicant is still detained". ${ }^{65}$

Expecting the judgment to be adopted in the second half of 2018, the scope of examination is restricted to a few preliminary issues. In view of the fact that the Contracting Parties intended the infringement proceedings as a last resort instrument, and that there are other dilatory States, one cannot but wonder about the specific circumstances which triggered the activation of this "nuclear option". Flagrant and/or systemic violations of human rights occur in other States as well, including Russia, Turkey, Ukraine and Hungary, ${ }^{66}$ but no such steps were taken against these.

There are various factors which probably helped the Committee of Ministers overcome the obstacle of the two-thirds majority. ${ }^{67}$ First, the victim in this case, Ilgar Mammadov is a wellknown, high profile political opponent. ${ }^{68}$ Support was expressed by the European Union, ${ }^{69}$ as

62 Interim Resolution CM/ResDH(2017)379 of 25 October 2017

63 Views of the Republic of Azerbaijan, CM/ResDH(2017)429, Appendix; para. 10.

64 Ibid., para. 23.

65 See, inter alia, Interim Resolution CM/ResDH(2015)43 (12 March 2015).

66 See e.g. PACE Resolution 2178 (2017) on The implementation of judgments of the European Court of Human Rights, noting in para. 6 that "Italy, the Russian Federation, Turkey, Ukraine, Romania, Hungary, Greece, Bulgaria, the Republic of Moldova and Poland have the highest number of non-implemented judgments and still face serious structural problems, some of which have not been resolved for over ten years."

67 ZASTROW, J.E. and ZIMMERMANN, A., "Council of Europe's Committee of Ministers Starts Infringement Proceedings in Mammadov v. Azerbaijan: A Victory for the International Rule of Law?”, February 5, 2018, available at https://bit.ly/2ElYKDy

68 See his blog at https://ilgarmammadov.livejournal.com/

69 Statement by the spokespersons of EU High Representative Catherine Ashton, and the European Commissioner for Enlargement and Neighbourhood Policy, Štefan Füle, on recent events in Azerbaijan: "The High Representative and the Commissioner are concerned that ... Mr. Ilgar Mammedov, leader and Presidential candidate of the Republican Alternative party [was] arrested". European Commission, Press Release, Brussels, 9 
well as prestigious human rights NGO-s, including Amnesty International and Human Rights Watch. $^{70}$

Second, the case involved a flagrant defiance of the obligations under the Convention. The applicant's imprisonment was based on his political activities; his detention formed part of an attempt to intimidate the opposition, engendering a widespread sense of fear among opposition forces; and the actual purpose of his detention had been to silence or punish him for criticising the government. Besides the violation of Arts. 5 and 6, the Court also found that Mammadov's rights were restricted for purposes other than those prescribed in the Convention, and that the authorities had not acted in good faith. ${ }^{71}$

Then, the measures required to comply with the judgment are relatively straightforward: release from prison. Measuring compliance in a situation stemming from structural problems would inevitably involve more complex issues, and would be less suitable to judicial scrutiny.

Finally, Azerbaijan is an easier target than other States, a few of them with a significantly higher number of non-implemented judgments. There are other, equally non-complying States, such as Russia or the UK, but these enjoy far more lobbying support among the other members of the Committee than Azerbaijan.

The judgment is eagerly awaited and further conclusions cannot be drawn beforehand. Nonetheless, a few points can be noted.

- It is already known that the judgment is expected in 2018, thus adopted within one year, which is relatively short as compared with other cases before the Court.

- Less clear is the scope of the judgment. Will the Court focus only on the Azerbaijani refusal to release Mammadov, and if yes, can it award just satisfaction; or will the Court also scrutinise the general measures taken by the State? $?^{72}$

- Though an unlikely scenario in view of the circumstances of the case, but what will happen if Azerbaijan releases the applicant before the Court adopts its judgment?

These are just a few questions to which the answer is as yet unknown. In fact, infringement proceedings do not entail any kind of legal sanction. Art. 46(5) ECHR stipulates that if the Court finds that the respondent State has refused to abide by the judgment, "it shall refer the case to the Committee of Ministers for consideration of the measures to be taken." If the Court finds no violation, "it shall refer the case to the Committee of Ministers, which shall close its examination of the case." Thus, should the Court find that Azerbaijan has failed to

\footnotetext{
February 2013, https://bit.ly/2QBpkLv . See also European Parliament resolution on Azerbaijan: the case of Ilgar Mammadov (2013/2668(RSP)), available at https://bit.ly/2PmHHUm. See also the statements released by the US (at https://bit.ly/2RyKyLl ) and the UK (at https://bit.ly/2y6f5Ia )

70 See the joint statement of Amnesty International and Human Rights of 20 October 2017, "Support Infringement Procedure under article 46.4 ECHR on Ilgar Mammadov v. Azerbaijan”, at https://bit.ly/2zYvtvJ

71 The Court found that "the actual purpose of the impugned measures was to silence or punish the applicant for criticising the Government and attempting to disseminate what he believed was the true information that the Government were trying to hide. In the light of these considerations, the Court finds that the restriction of the applicant's liberty was applied for purposes other than" those prescribed in the Convention. Para. 143.

GLAS, L.R., "The Committee of Ministers goes nuclear: infringement proceedings against Azerbaijan in the case of Ilgar Mammadov", December 20, 2017, https://bit.ly/2DmAAcD
} 
execute the judgment, the only difference is that, besides the classification of the Committee of Ministers, now we have the Court's statement on that as well.

\title{
V. CONCLUSIONS
}

The case against Azerbaijan is the first attempt to invoke the new procedure, thus it will be interesting to see how it works in practice. The major issue is whether it can provide a workable solution to the ineffective national implementation and inadequate execution of Court judgments, which are the main problems facing the Convention system.

Failing to implement judgments of the Court in a timely and effective manner undermines the rule of law, and poses significant challenges for the credibility and legitimacy of the Convention system. Unfortunately, the last decades saw the increasing number of States which challenge the authority of international institutions. These various developments, taken together, are cause for real concern. As the Commissioner for Human Rights noted,

\begin{abstract}
Prolonged non-implementation is problematic, even if it is true that complex problems do take time to resolve. Reforms can legitimately take time to design and implement. Nevertheless, the rule of law requires that all judgments should be implemented promptly, fully and effectively. Prompt execution of domestic court decisions is one of the hallmarks of a democratic society. The same should apply for execution of international judgments. ${ }^{73}$
\end{abstract}

Admittedly, Art. 46 leaves a very wide margin of appreciation to States in finding legislative and other solutions adapted to national circumstances. Yet, this discretion is not unlimited: the Committee of Ministers is vested with the power to scrutinize the execution of judgments. The reliability of this peer review is disputed. It is argued that either States lack incentives to monitor other States' human rights compliance, or just the opposite, heightened interest in human rights in other States is frequently due to self-interest. ${ }^{74}$ Such criticism seems justified in the case of the Universal Periodic Review carried out by the Human Rights Council, ${ }^{75}$ however, an in-depth empirical analysis of the peer review mechanism in the Council of Europe carried out by Çalı and Koch shows that there are adequate formal and informal

\footnotetext{
73 Nils Muižnieks (Commissioner for Human Rights of the Council of Europe), Human Rights Comment: Non-implementation of the Court's judgments: our shared responsibility, Strasbourg 23/08/2016, https://bit.ly/2E6pLfv

74 ÇALI and KOCH (2014), at p. 302.

75 From the author, see KOMANOVICS, A., "The Human Rights Council and the Universal Periodic Review: Is it more than a public relations exercise? in: Balogh, Zs.Gy. (ed), Studia Iuridica Auctoritate Universitatis Pécs Publicata No. 150 (Pécs, 2012), pp. 119-146; KOMANOVICS, A. and MAZUR-KUMRIĆ, N., "The Human Rights Council and the Universal Periodic Review: A novel method of promoting compliance with human rights”, in: DRINÓCZI, T., ŽUPAN, M., ERCSEY, Zs., VINKOVIĆ, M. (eds.): Contemporary legal challenges: EU - Hungary - Croatia, Faculty of Law, University of Pécs AND Faculty of Law, J.J. Strossmayer University of Osijek 2012, pp. 641-669; KOMANOVICS, A., "Strengthening the Human Rights Treaty Bodies: A Modest but Important Step Forward", Pécs Journal of International and European Law - 2014/I, pp. 7-29 (available at https://bit.ly/1UkY6UV). See also RAHMANI-OCORA, "Giving the Emperor Real Clothes: The UN Human Rights Council”, 12 Global Governance (2006) pp. 15-20, p. 15; VENGOECHEA-BARRIOS, J., "The Universal Periodic Review: A New Hope for International Human Rights Law or a Reformulation of Errors of the Past?", 12 Revista Colombiana de Derecho Internacional (2008) pp. 101-116, p. 103; VIÉGAS-SILVA, M., "El nuevo Consejo de Derechos Humanos de la Organización de las Naciones Unidas: Algunas consideraciones sobre su creación y su primer año de funcionamiento", 12 Revista Colombiana de Derecho Internacional (2008) pp. 35-66, p. 41; MATIYA, J., "Repositioning the international human rights protection system: the UN Human Rights Council”, 36 Commonwealth Law Bulletin (2010) pp. 313-324, p. 314.
} 
institutional constraints in the Committee of Ministers to secure the reliability of the system. ${ }^{76}$ As the implementation process may be very technical, the Court is not always in the best position to address this task, particularly when the execution takes time or seems difficult.

Despite their flaws, hybrid models of compliance monitoring which combine political and judicial elements, may be effective in facilitating human rights compliance. Due to the "the rising cost of acquiring a reputation for being unreliable and untrustworthy", States generally care about their reputation and endeavour to be seen as a respectable and law-abiding member of international society. ${ }^{77}$ It remains to be seen how the Court decides in the proceedings against Azerbaijan, and what might be achieved in case the Court agrees with the Committee of Ministers. ${ }^{78}$

76 ÇALI and KOCH (2014) at p. 311 argue that "peers do admit that they are politically motivated, build alliances, have enemies and friends and do not show equal interest in each and every human rights case. They are, however, constrained by the institutional setting in which they operate."

77 HENRIKSEN (2017) at p. 17. See also BREWSTER, R., "Unpacking the State's Reputation", 50 Harvard International Law Journal (2009) 231, BREWSTER, R. (2013) Reputation in International Relations and International Law Theory. In Dunoff, J., and Pollack, M., Interdisciplinary Perspectives on International Law: The State of the Art. New York: Cambridge University Press, pp. 524-43.

78 Please note that according to Azeri Times, Baku "hinted at the release of Ilgar Mammadov in connection with serving two-thirds of the term of punishment. ... In addition to releasing on parole, pardon may be announced. However, Ilgar Mammadov has repeatedly stated that he will not write a petition for pardon. But the law does not exclude pardon even without the request of the convict. ... Finally, the Supreme Court may, in pursuance of the ECHR decision, release Mammadov on justifiable grounds. However, such a scenario looks unrealistic." 8 December 2017, https://bit.ly/2y8sjo1. Is this an evidence for the impact of "naming and shaming"? 


\section{BIBLIOGRAPHY}

\section{Books and articles}

ABASHIDZE, A.Kh., ILYASHEVICH, M.V. and SOLNTSEV, A.M., "Anchugov \& Gladkov v. Russia", American Journal of International Law, 111 (2017), pp. 461-468

BÉKÉSI, L., The 12-Year Cycles - Society and Economy, AULA (1994/1.) pp.105-108

BLACKBURN, R. and POLIAKIEWICZ, J., Fundamental rights in Europe: The European Convention on Human Rights and its member states, 1950-2000, Oxford University Press, Oxford, 2001

BOBEK, M. (ed.), Selecting Europe's Judges: A Critical Review of the Appointment Procedures to the European Courts, Oxford University Press, 2015

BREWSTER, R., "Reputation in International Relations and International Law Theory". In Dunoff, J., and Pollack, M., Interdisciplinary Perspectives on International Law: The State of the Art. New York: Cambridge University Press, 2013, pp. 524-43.

BREWSTER, R., “Unpacking the State's Reputation”, 50 Harvard International Law Journal (2009), pp. 231269

COLE, W., "Mind the Gap: State Capacity and the Implementation of Human Rights Treaties. International Organization 69 (2015), pp. 405-41

ÇALI, B. and KOCH, A., "Foxes Guarding the Foxes? The Peer Review of Human Rights Judgments by the Committee of Ministers of the Council of Europe", Human Rights Law Review, 2014, pp. 301-325

D'AMBROSIO, D.R., "The Supremacy of the Russian Constitutional Court? Summary of Venice Commission Opinion no. 832/2015”, EHRAC Bulletin | Winter 2016, pp. 10-11

DE LONDRAS, F. and DZEHTSIAROU, K., "Mission Impossible? Addressing Non-execution through Infringement Proceedings in the European Court of Human Rights", International and Comparative Law Quarterly 66 (2017), pp. 467-490

FRANCK, T.M., The Power of Legitimacy Among Nations, Oxford University Press, 1990

GOLDSMITH, J., and POSNER, E., The Limits of International Law, New York: Oxford University Press, 2005

GOODMAN, R., and JINKS, D., "Incomplete Internalization and Compliance with Human Rights Law", European Journal of International Law 19 (2008), pp. 725-48.

GUZMAN, A., How International Law Works: A Rational Choice Theory, Oxford University Press, 2008

HENRIKSEN, A., International Law, Oxford University Press, 2017

HIGGINS, R., "The United Nations at 70 years: The Impact upon International Law", International and Comparative Law Quarterly 65 (2016), pp. 1-19

KELLER, H. and STONE SWEET, A. (eds.), A Europe of rights. The impact of the ECHR on National Legal Systems, Oxford University Press, 2006

KOMANOVICS, A. and MAZUR-KUMRIĆ, N., "The Human Rights Council and the Universal Periodic Review: A novel method of promoting compliance with human rights”. In: Drinóczi, T., Župan, M., Ercsey, Zs., Vinković, M. (eds.): Contemporary legal challenges: EU - Hungary - Croatia, Faculty of Law, University of Pécs and Faculty of Law, J.J. Strossmayer University of Osijek 2012, pp. 641-669

KOMANOVICS, A., “Az Emberi Jogok Európai Bíróságának ítélete az orosz melegpropaganda tilalmáról” [Judgment of the European Court of Human Rights on the ban of Russia on the promotion of homosexuality], Jogesetek Magyarázata 2018/1, Vol. IX Issue 1, pp. 69-76, available at https://bit.ly/2OF0Rrp

KOMANOVICS, A., "Strengthening the Human Rights Treaty Bodies: A Modest but Important Step Forward", Pécs Journal of International and European Law - 2014/I, pp. 7-29 (available at https://bit.ly/1UkY6UV)

KOMANOVICS, A., "The Human Rights Council and the Universal Periodic Review: Is it more than a public relations exercise?" In: Balogh, Zs.Gy. (ed), Studia Iuridica Auctoritate Universitatis Pécs Publicata No. 150 (Pécs, 2012), pp. 119-146 
KOMANOVICS, A., "Transición del compromiso al cumplimiento: eficacia de los tribunales internacionales de derechos humanos", Anuario da Facultade de Dereito da Universidade da Coruña, № 20, 2016, págs. 321-349; available at https://bit.ly/2OM5U9m

LAMBERT-ABDELGAWAD, E, 'The Court as a part of the Council of Europe: the Parliamentary Assembly and the Committee of Ministers' in Føllesdal, A., Peters, B. and Ulfstein, G. (eds), Constituting Europe: The European Court of Human Rights in a National, European and Global Context, Cambridge University Press 2013, 263-300

MACKENZIE, R. and SANDS, P., "Judicial Selection for International Courts: Towards Common Principles and Practices," in Kate Malleson and Peter H. Russell (eds.), Appointing Judges in an Age of Judicial Power: Critical Perspectives From Around the World, University of Toronto Press, 2006

MACKENZIE, R., MALlESON, K., MARTIN, P., SANDS, P., Selecting International Judges: Principle, Process, and Politics, Oxford University Press, 2010

MATIYA, J., "Repositioning the international human rights protection system: the UN Human Rights Council", Commonwealth Law Bulletin 36 (2010), pp. 313-324

RAHMANI-OCORA, "Giving the Emperor Real Clothes: The UN Human Rights Council", 12 Global Governance (2006), pp. 15-20

VAN DIJK, P., VAN HOOF, F., VAN RIJN, A., and ZWAAK, L. (eds), Theory and Practice of the European Convention on Human Rights, 4th edition, Intersentia 2006

VENGOECHEA-BARRIOS, J., "The Universal Periodic Review: A New Hope for International Human Rights Law or a Reformulation of Errors of the Past?", 12 Revista Colombiana de Derecho Internacional (2008), pp. 101-116

VIÉGAS-SILVA, M., "El nuevo Consejo de Derechos Humanos de la Organización de las Naciones Unidas: Algunas consideraciones sobre su creación y su primer año de funcionamiento", 12 Revista Colombiana de Derecho Internacional (2008), pp. 35-66

\section{Other documents}

MUIŽNIEKS, N., Commissioner for Human Rights of the Council of Europe, Human Rights Comment: Nonimplementation of the Court's judgments: our shared responsibility, Strasbourg 23 August 2016, https://bit.ly/2E6pLfv

MUIŽNIEKS, N., Council of Europe Commissioner for Human Rights of the Council of Europe, Written evidence (VEP 0053), UK Parliament Joint Committee on the draft Voting Eligibility (Prisoners) Bill, Oral and Written Evidence; 2013, pp. 520-522, at p. 522; https://bit.ly/2NubgBj

Report of the International Commission of Jurists and the Open Society Justice Initiative, Strengthening from Within. Law and Practice in the Selection of Human Rights Judges and Commissioners, Open Society Foundations, 2017

European Commission, Press Release, Brussels, 9 February 2013, https://bit.ly/2QBpkLv

European Parliament resolution on Azerbaijan: the case of Ilgar Mammadov (2013/2668(RSP)), at https://bit.ly/2PmHHUm

Amnesty International, Report on Azerbaijan 2017/2018, https://bit.ly/109vrUU

Human Rights Watch, Report on Azerbaijan, https://bit.ly/2Qz7qsM

United States Department of State, Human Rights Report on Azerbaijan, https://bit.ly/2QCPwFH

Joint statement of Amnesty International and Human Rights of 20 October 2017, "Support Infringement Procedure under article 46.4 ECHR on Ilgar Mammadov v. Azerbaijan", https://bit.ly/2zYvtvJ

AKSENOVA, M, "Anchugov and Gladkov is not Enforceable: the Russian Constitutional Court Opines in its First ECtHR Implementation Case”, 25 April 2016, https://bit.ly/2QxzFbh 
ARMAS-CARDONA, G., "The Dissent in Bayev and Others v. Russia: A Window into an Illiberal World View", 7 July 2017, https://bit.ly/2Rzv210

BUYSE, A., "Possible Infringement Proceedings Against Russia", 14 August 2012, https://bit.ly/2NvxItR

CHAEVA, N., "The Russian Constitutional Court and its Actual Control over the ECtHR Judgment in Anchugov and Gladkov", 26 April 2016, https://bit.ly/2OIb4TN

FALCETTA, S., "Critical consideration of the 'disturbing' views of ECHR Judges Pejchal and Wojtyczek on same-sex relationships”, 16 December 2017, https://bit.ly/2RwUODP

GLAS, L.R., "The Committee of Ministers goes nuclear: infringement proceedings against Azerbaijan in the case of Ilgar Mammadov", 20 December 2017, https://bit.ly/2DmAAcD

JOHNSON, P., "Homophobia in the European Court of Human Rights”, 13 July 2017, https://bit.ly/2Plou5m

LAVRYSEN, L., “Bayev and Others v. Russia: on Judge Dedov's outrageously homophobic dissent”, 13 July 2017, available at https://bit.ly/2uA4KEt

PHILIPPOV, I., "Russian Constitutional court denies enforcement of ECHR decision on Yukos", 25 January 2017, https://bit.ly/2ICMT6m

ZASTROW, J.E. and ZIMMERMANN, A., "Council of Europe's Committee of Ministers Starts Infringement Proceedings in Mammadov v. Azerbaijan: A Victory for the International Rule of Law?", February 5, 2018, https://bit.ly/2ElYKDy

\section{Council of Europe documents}

Convention for the Protection of Human Rights and Fundamental Freedoms, ETS No.005, Rome, 4 November 1950

Protocol No. 14 to the Convention for the Protection of Human Rights and Fundamental Freedoms, amending the control system of the Convention. Strasbourg, 13 May 2004, and its Explanatory Report

Committee of Ministers, Supervision of the Execution of Judgments and Decisions of the European Court of Human Rights, 10th Annual Report of the Committee of Ministers - 2016, Council of Europe, March 2017

Committee of Ministers, Supervision of the Execution of Judgments and Decisions of the European Court of Human Rights. 11th Annual Report of the Committee of Ministers - 2017, available at https://bit.ly/2BZTMed

Rules of the Committee of Ministers for the supervision of the execution of judgments and of the terms of friendly settlements (2006)

Committee of Ministers, Interim resolutions in Mammadov v. Azerbaijan

Interim Resolution CM/ResDH(2015)43 (12 March 2015), https://bit.ly/2E218jU

Interim Resolution CM/ResDH(2015)156 (24 September 2015), https://bit.ly/2OHg2QQ

Interim Resolution CM/ResDH(2016)144 (8 June 2016), https://bit.ly/2PmGRqG

Interim Resolution CM/ResDH(2017)379 (25 October 2017), https://bit.ly/2RAphRf

Interim Resolution CM/ResDH(2017)429 (5 December 2017), https://bit.ly/2QzT3UW

European Commission for Democracy Through Law (Venice Commission), Report on the Implementation of International Human Rights Treaties in Domestic Law and the Role of Courts (Rome, 10-11 October 2014), CDL-AD(2014)036

European Commission for Democracy Through Law (Venice Commission), Interim Opinion on the amendments to the Federal Constitutional Law on the Constitutional Court of the Russian Federation, Opinion no. 832/2015, CDL-AD(2016)005 (Interim Opinion), available at https://bit.ly/1Mkvw1G 
European Commission for Democracy Through Law (Venice Commission), Russian Federation. Final Opinion on the amendments to the Federal Constitutional Law on the Constitutional Court, Opinion no. 832/2015, CDL$\mathrm{AD}(2016) 016$, available at https://bit.ly/1UhhnIn

Amendments to the Federal Constitutional Law on the Constitutional Court of the Russian Federation of 14 December 2015, reproduced in European Commission for Democracy Through Law (Venice Commission), CDL-REF(2016)006, Strasbourg, 20 January 2016, available at https://bit.ly/2y8tRyb

PACE Doc. 11767 of 1 December 2008, Nomination of candidates and election of judges to the European Court of Human Rights. Report of the Committee on Legal Affairs and Human Rights; Rapporteur: Christopher Chope, available at https://bit.ly/2QyB2X6

PACE Resolution 2178 (2017) on The implementation of judgments of the European Court of Human Rights

Steering Committee for Human Rights, Report on the longer-term future of the system of the European Convention on Human Rights, Strasbourg, 11 December 2015, CDDH(2015)R84 Addendum I

Annual Report of the European Court of Human Rights 2015, available at https://bit.ly/2E5XA0a

Annual Report of the European Court of Human Rights 2016, available at https://bit.ly/2zYCUDk

Annual Report of the European Court of Human Rights 2017, available at https://bit.ly/2C2r0tk

Bayev and Others v. Russia (Appl. nos. 67667/09, 44092/12 and 56717/12, Judgment of 20 June 2017)

Z.A. and Others v. Russia (Appl. nos. 61411/15 and three others, Judgment of 28 March 2017)

Orlandi and Others v Italy (Appl. nos. 26431/12; 26742/12; 44057/12 and 60088/12, Judgment of 14 December 2017)

Anchugov and Gladkov v. Russia (Appl. nos. 11157/04 and 15162/05, Judgment of 4 July 2013)

OAO Neftyanaya Kompaniya Yukos v. Russia (Appl. no. 14902/04, Judgment of 20 September 2011)

Isayeva v. Russian Federation (Appl. no. 57950/00; Judgment of 24 February 2005)

Trabajo Rueda v. Spain (Appl. no. 32600/12, Judgment of 30 May 2017)

Marckx v. Belgium (Appl. no. 6833/74, Judgment of 13 June 1979)

E.B. v France (Appl. No. 43546/02, Judgment of 22 January 2008)

Mammadov v. Azerbaijan (Appl. no. 15172/13, Judgment of 22 May 2014) 